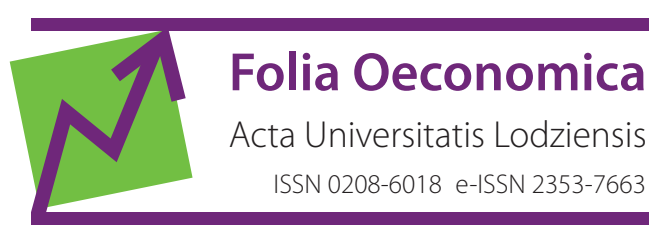

www.czasopisma.uni.lodz.pl/foe/

4(343) 2019

DOI: http://dx.doi.org/10.18778/0208-6018.343.03

\author{
Wanda Skoczylas \\ University of Szczecin, Faculty of Economics and Management \\ Department of Management Accounting and Controlling, wanda@wneiz.pl
}

\author{
Barbara Batóg \\ University of Szczecin, Faculty of Economics and Management \\ Department of Operations Research and Applied Mathematics in Economics \\ barbara.batog@usz.edu.pl
}

\title{
A Dynamic Approach to a Comparative Evaluation of Financial Performance of Sections and Sectors of the Polish Economy
}

\begin{abstract}
Financial performance of companies and their groups is of major interest to all stakeholders. As a result, they assess categories such as profitability, financial liquidity, financial independence, and risk. Separate analyses carried out for each of those elements alone do not always deliver conclusive findings, which is where synthetic methods are helpful. A ranking based on the taxonomic measure of development is one of such methods. The aim of the paper is, firstly, to present opportunities for using a dynamic version of the taxonomic measure of development in a comparative and complex assessment of financial performance in PKD divisions (Polish Classification of Activity), and, secondly, to evaluate changes in this area in the years 2014-2016. The data used for developing the ranking were sourced from the joint publication of industry indicators by the Financial Analysis Commission at the Research Council of the Accountants Association in Poland and InfoCredit, and from the Statistics Poland.
\end{abstract}

Keywords: financial performance, taxonomic measure of development

JEL: M21, M40, C38 


\section{Introduction}

Financial performance of individual companies, their subclasses, classes, groups or divisions is subject to constant monitoring. Good financial condition leads to growth and development, and guarantees satisfaction to all stakeholders. Poor performance, on the other hand, may lead to bankruptcy, which usually has negative consequences for the achievement of goals of all the stakeholders involved.

An evaluation of financial performance is a multidimensional assessment. It is based on multiple criteria, including profitability, financial liquidity, financial independence, and risk. Results of an analysis of individual criteria create an incomplete picture of performance. For this reason, synthetic measures are sought which would enable a more generalised performance evaluation as well as an early identification of opportunities and threats. It poses a challenge not only to a comparative analysis of individual companies but also subclasses, classes, groups, and divisions. A comparative evaluation of financial performance of, for instance, divisions against other divisions delivers useful information both to the government for the purpose of policy making and to all stakeholders for the purpose of decision making. What is essential here is not the actual figures at any given moment but the tendencies, which can be recognised even based on three different observations made over time.

Financial performance of companies and their groups is influenced by a number of factors. In general, they can be grouped into external and internal factors. The first group includes macroeconomic, political, legal, social, technological and environmental, etc. factors as well as industry-related factors, among which M. Porter identifies intensity of competitive rivalry, threat of new entry, threat of substitution, supplier power and buyer power. Most of these factors are beyond the management's control. Internal factors, on the other hand, are those which are directly related to the decisions made by the company. Identification of the company's position among its peers in terms of the basic factor - i.e. the country's current economy - points to the significance of other factors influencing financial performance.

The aim of the paper is, firstly, to present opportunities for using a dynamic version of the taxonomic measure of development in a comparative and complex assessment of financial performance in PKD divisions, and, secondly, to evaluate changes in this area in the years 2014-2016. The analysis will enable the identification of divisions with the lowest and highest risk related to the current financial performance, which should provide significant support to all the stakeholders in the decision making process.

For the purpose of developing the ranking of divisions, the following sources were used: industry indicators published jointly by the Financial Analysis Commission at the Research Council of the Accountants Association in Poland and InfoCredit (Dudycz, Skoczylas, 2016; 2017; 2018), and statistical data available from 
the Statistics Poland. The methods employed included: critical literature review methods, financial analysis methods and statistical methods such as a correlation analysis and a dynamic version of the taxonomic measure of development.

\section{Directions and methods of evaluating financial performance in business organisations}

Current financial performance is a reflection of all operations of business entities involving their assets, financial condition and results of their operations (Nowak, 2017: 41). The holistic character of this category and its relevance to the evaluation of both past performance and future growth opportunities makes it a topic of multidirectional and multidimensional investigations performed by all their stakeholders. Depending on the investigator, the analysis may be either internal or external. The former type of analysis is performed inside the company using all the available information, and as such can be a causal analysis incorporating elements of the company's operations. The latter type of analysis is carried out by stakeholders from the company's environment and it is based on the information available to the public. The scope of the external analysis is inevitably narrower although the information gap has been recently reduced by regulations obliging certain entities to disclose nonfinancial information (Directive 2014/95/EU, the Act on Accounting). In the current study, the external analysis of internal factors is applied. An analysis and evaluation of financial performance can focus on an individual company, affiliated companies or separate groups of companies. This assessment is multidirectional; current performance can be compared and contrasted with other periods, plans or other entities. This last direction is believed to deliver the greatest cognitive value. Identification of the company's position among similar companies leads to a variety of positive or negative reflections on the reasons behind the present situation and forms the foundation for decision making. This value is further increased by information on the financial situation of the economic sector and the trend in its evolution over the minimum required for an assessment period of three consecutive years.

An evaluation of financial performance is a multidimensional assessment whose main focus is on profitability, financial liquidity, efficiency, debt (financial independence), and risk (Sierpińska, Jachna, 2004: 15; Waśniewski, Skoczylas, 2004: 10-12; Gabrusewicz, 2014: 24-32). For this reason, developing a ranking of entities so as to make comparisons among them is difficult, which is why certain simplifications are made - only one indicator, e.g.: sales, net profit or economic value added serves as a reference. Such a methodological assumption which limits the analysis solely to the final results (defined in various ways) disregards other - equally important - evaluation criteria such as financial liquidity, debt and risk. 
In response to this approach, synthetic measures are sought. In banks, credit risk assessment employs credit scoring. More and more often, due to their advantages, taxonomic measures are employed (e.g.: Nowak, 1990; Stawicki, Sojak, 2001; Siemińska, 2002: 262-276; Pietrzykowski, Kobus, 2006; Siudek, 2006; Witkowska, Witkowski, 2014: 126-134; Zielińska-Chmielewska, Strózik, 2015: 397-408; Skoczylas, Batóg, 2017: 387-397; Skoczylas, Batóg, Sobieraj, 2017). In this group of methods, in turn, structural classifications, and discriminative analysis in particular, have been enjoying great popularity for many years (e.g.: Hadasik, 1998; Hołda, 2001; Hamrol, Czajka, Piechocki, 2004; Mączyńska, Zawadzki, 2006). Ranking methods, including the taxonomic measure of development, are appreciated for their cognitive value, yet they still remain underused.

\section{Taxonomic measure of development as the base of objects ordering according to characteristics of their financial situation}

The taxonomic measure of development allows us to order objects according to their attributes. In Poland, the taxonomic measure of development was introduced by Z. Hellwig (1968). He proposed the measure based on the distance between an individual object and the ideal solution (or the negative-ideal solution) 1 . The approach proposed by Hwang and Yoon (1981) was slightly different. Their method TOPSIS (Technique for Order Preference by Similarity to Ideal Solution) uses distances from the ideal solution and from the negative-ideal solution at the same time.

In both methods, analysed attributes could have a stimulant, nominant or destimulant character. The TOPSIS method assumes that each attribute is monotonically increasing or monotonically decreasing. In the current research, only stimulants and nominants were present. Hence nominants should be transformed into stimulants. In the literature, many ways of transformation can be found (Nowak, 1990; Gatnar, Walesiak, 2004; Młodak, 2006). The applied transformation is given by formula (1).

$$
x_{i j}=\left\{\begin{array}{ccc}
x_{0 i j} & \text { gdy } & x_{0 i j} \leq M_{j} \\
2 M_{j}-x_{0 i j} & \text { gdy } & x_{0 i j}>M_{j}
\end{array},\right.
$$

where:

$i$-object's number,

1 In the literature, different names of the ideal solution and negative-ideal solution can be found: the upper pattern (ideal object, upper pole) and the lower pattern (anti-ideal object, lower pole). 
$i=1,2, \ldots, n$,

$n$ - number of objects,

$j=1,2, \ldots, k$,

$k$ - number of variables,

$j$ - variable's number,

$M_{j}$ - median of $j$-th variable,

$x_{0 i j}$ - original value of the $j$-th variable (nominant) for the $i$-th object,

$x_{i j}$ - value of the $j$-th variable (nominant) for the $i$-th object after the transformation into a stimulant.

The second step of TOPSIS procedure is normalisation which allows for comparison across the variables. The zero unitarisation method was applied - see formula (2) (Kukuła, 2000; Batóg, 2003).

$$
z_{i j}=\frac{x_{i j}-\min _{j}}{\max _{j}-\min _{j}},
$$

where:

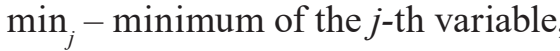
$\max _{j}$ - maximumof the $j$-th variable, $z_{i j}$ - value of the $j$-th variable for the $i$-th object after normalisation.

The values of $z_{i j}$ lie in the interval $\langle 0,1\rangle$. In the next step, the distances between every object and the ideal solution as well as the distances between every object and the negative-ideal solution were calculated. The ideal solution is the theoretical object with the biggest values of variables after normalisation and the negative-ideal solution is the theoretical object with the lowest values of variables after normalisation. In the case of application of formula (2), all variables for the ideal solution take value 1 and all variables for the negative-ideal solution take value 0 . The distances were calculated using the formula for the Euclidean distance.

In TOPSIS, measures of development (relative closeness) are computed by means of formula (3).

$$
q_{i}=\frac{d_{i 0}}{d_{i 0}+d_{i 1}}
$$

where:

$q_{i}$-taxonomic measure of development for the $i$-th object,

$d_{i, 0}$ - distance between the $i$-th object and the negative-ideal solution,

$d_{i, 1}$ - distance between the $i$-th object and the ideal solution.

The taxonomic measure of development lies in the interval $\langle 0,1\rangle$. The closer its value for a given object reaches 1 , the higher the position of this object in the ranking. 
The aim of the research was to assess the rankings for three years therefore the dynamic version of TOPSIS was used. The dynamic version of TOPSIS means that transformation of nominants into stimulants and normalisation were conducted for all three years at the same time. This kind of approach allows for comparisons jointly across objects and years.

\section{Methodological assumptions and findings}

The study focused on the investigation of individual divisions of the Polish Classification of Activity (PKD) $2007^{2}$, for which financial indicators are estimated and published by the Financial Analysis Commission at the Research Council of the Accountants Association in Poland in collaboration with InfoCredit. Their calculation was based on information published in financial statements (prepared in accordance with the Accounting Act) of 47,864 enterprises in 2014, 52,311 enterprises in 2015 and 42,406 enterprises in 2016. Those enterprises conducted their business activity throughout Poland. From the point of view of their size measured by the sales revenues or employment level (similarly as in the whole economy), those were mainly micro and small enterprises.

The study covered the years 2014-2016. Considering the significance of external factors for financial performance of individual divisions, gross value added for the entire period is worth summarising (see Table 1).

Table 1. Gross value added in the years 2014-2016

\begin{tabular}{|l|c|c|c|c|c|c|}
\hline \multicolumn{1}{|c|}{ Item } & $\mathbf{2 0 1 4}$ & $\mathbf{2 0 1 5}$ & $\mathbf{2 0 1 6}$ & \multicolumn{3}{c|}{ Dynamics } \\
\cline { 5 - 7 } & & & $\mathbf{2 0 1 5 / 2 0 1 4}$ & $\mathbf{2 0 1 6 / 2 0 1 5}$ & $\mathbf{2 0 1 6 / 2 0 1 4}$ \\
\hline $\begin{array}{l}\text { Total gross value added } \\
\text { (current prices } \\
\text { in PLN million) }\end{array}$ & $1,525,005$ & $1,596,366$ & $1,642,904$ & 104.7 & 102.9 & 107.7 \\
\hline $\begin{array}{l}\text { of which: } \\
\text { Sector 1 (A) }\end{array}$ & 44,939 & 39,630 & 44,308 & 88.2 & 111.8 & 98.6 \\
\hline Sector 2 (B, C, D, E) & 386,652 & 417,216 & 435,734 & 107.9 & 104.4 & 112.7 \\
\hline Sector 3 (F) & 119,680 & 127,481 & 114,572 & 106.5 & 89.9 & 95.7 \\
\hline Sector 4 (G, H, I, J) & 444,688 & 466,884 & 479,231 & 105.0 & 102.6 & 107.8 \\
\hline Sector 5 (K, L) & 149,071 & 143,324 & 157,659 & 96.1 & 110.0 & 105.8 \\
\hline $\begin{array}{l}\text { Sector 6 (M, N, O, P, } \\
\text { Q, R, S) }\end{array}$ & 379,975 & 401,831 & 411,400 & 105.8 & 102.4 & 108.3 \\
\hline
\end{tabular}

*Gross value added is an essential element of GDP; it is calculated as the difference between the global output and intermediate consumption.

\section{Source: own study based on data from Statistics Poland (b)}

2 Statistics Poland (a). 
As shown in Table 1, gross value added was rising throughout the entire period of study, although in 2016 that growth was less dynamic. Declining gross value added can be observed in sectors 1, owing to a drop in 2015, and 3, where good performance in 2015 was followed by much poorer in the following year. Other sectors reported ambiguous results. The most dynamic growth in gross value added was observed for sector 2. In the less favourable year 2015, sector 5 saw a dynamic growth in gross value added.

For the purpose of evaluating financial performance in this study, the following indicators and their arithmetic means were used:

$\mathrm{x} 1$ - return on assets - stimulant,

$\mathrm{x} 2$ - return on equity - stimulant,

x3 - net profit margin - stimulant,

x4 - return on sales - stimulant,

x5 - EBITDA to sales ratio - stimulant,

$\mathrm{x} 6$ - cash ratio - nominant,

$\mathrm{x} 7$ - quick ratio - nominant,

x8 - current ratio - nominant,

x9 - days sales outstanding - nominant,

x10 - days payable outstanding - nominant,

x11 - inventory turnover - nominant,

x12 - equity and long-term reserves to fixed assets ratio - nominant,

x13 - fixed assets to total assetsratio - nominant,

$\mathrm{x} 14$ - total debt ratio - nominant.

The list of divisions under analysis includes 79 divisions for which 2014-2016 data were available.

Before calculating taxonomic measures of development, correlation coefficients were estimated for all the indicators for individual years since the explanatory variables should not be strongly correlated. Given that absolute correlation coefficients between indicators should not exceed 0.8 , the following three indicators needed to be excluded from further analysis:

$\mathrm{x} 2$ - return on equity,

$\mathrm{x} 7$ - quick ratio,

$\mathrm{x} 8$ - current ratio.

First, the analysis was carried out for 6 sectors. Based on the information on PKD divisions comprising each sector, indicators for each sector were next calculated as weighted arithmetic means - weighting the division means by the number of companies in each division of the sector. The results are summarised in Table 2.

Table 2 reveals that the best financial performance was reported for companies in sector 2: Industry, and it gradually improved over the entire period. Companies in that sector outperformed their peers in the last year of analysis. Other sec- 
tors which saw a gradual improvement in their financial performance were sectors 6 and 5. Companies from sectors 3 and 4 suffered from a deterioration in their financial performance in 2016 following a temporary improvement in 2015. And companies in sector 1 were clearly in the worst financial condition. Financial performance of individual sectors was usually consistent with the tendencies in gross value added, with two exceptions however - sector 5 in 2015, and sectors 1 and 4 in 2016. In the first case, a drop in gross value added was accompanied by an improvement in financial performance, whereas in the other case the opposite can be observed.

Table 2. Ranking of sectors

\begin{tabular}{|c|l|r|r|c|}
\hline \multicolumn{2}{|c|}{ Sector } & \multicolumn{3}{c|}{ Rank } \\
\cline { 3 - 5 } \multicolumn{2}{|c|}{} & $\mathbf{2 0 1 4}$ & $\mathbf{2 0 1 5}$ & $\mathbf{2 0 1 6}$ \\
\hline 1 & Agriculture, forestry, hunting and fishing: section A & 14 & 17 & 18 \\
\hline 2 & Industry: sections B, C, D, E & 3 & 2 & 1 \\
\hline 3 & Construction: section F & 13 & 5 & 16 \\
\hline 4 & Market services: sections G, H, I, J & 9 & 7 & 11 \\
\hline 5 & Financial services: sections K, L & 15 & 12 & 10 \\
\hline 6 & Other services: sections M, N, O, P, Q, R, S & 8 & 6 & 4 \\
\hline
\end{tabular}

Source: own study

A more detailed summary of financial performance of individual divisions in sector 1 is shown in Table 3 .

Table 3. Ranking of PKD divisions in sector 1: Agriculture, forestry, hunting and fishing: section A

\begin{tabular}{|c|c|c|c|}
\hline \multirow{2}{*}{ Division } & \multicolumn{3}{|c|}{ Rank } \\
\cline { 2 - 4 } & $\mathbf{2 0 1 4}$ & $\mathbf{2 0 1 5}$ & $\mathbf{2 0 1 6}$ \\
\hline 01 & 2 & 3 & 5 \\
\hline 02 & 6 & 9 & 1 \\
\hline 03 & 7 & 4 & 8 \\
\hline
\end{tabular}

Source: own study

Companies in Division 03 Fishing and aquaculture outperformed their peers. In the other two divisions, the situation continued to worsen, although in each year companies from Division 01 Crop and animal production, hunting, including service activities, were ranked much higher than those in Division 02 Forestry and logging.

Financial performance of companies representing divisions comprising sector 2: Industry, and its changes over time are summarised in Table 4.

In the ranking for the sector: Industry, the leaders were companies from Division 20 Manufacture of chemicals and chemical products, and their situation continued to gradually improve. Companies from Division 25 Manufacture of fabri- 
cated metal products, except machinery and equipment also held a high position, yet it gradually deteriorated. Two divisions reported exceptionally dynamic growth in their ranks: Division 21 Manufacture of basic pharmaceutical substances and medicines and other pharmaceutical products as well as Division 24 Manufacture of metals. The lowest position was found for Division 6, i.e. Extraction of crude petroleum and natural gas, and it remained relatively stable over time. Extremely dynamic changes over time can be observed for the ranks of Division 11 Manufacture of beverages. Companies from that division graduated from the $25^{\text {th }}$ position to number 1 in the following year to drop again to the $35^{\text {th }}$ position in 2016. During the three-year period considered, a gradual decline can also be seen for Divisions 26 Manufacture of computer, electronic and optical products and 29 Manufacture of motor vehicles, trailers and semi-trailers excluding motorcycles. Compared to 2015, the worsening of the financial situation also occurred in Division 27 Manufacture of electrical equipment.

Table 4. Ranking of PKD divisions in sector 2: Industry: PKD sections B, C, D, E

\begin{tabular}{|c|c|c|c|c|c|c|c|c|c|c|c|}
\hline \multirow{2}{*}{ Division } & \multicolumn{3}{|c|}{ Rank } & \multirow{2}{*}{ Division } & \multicolumn{3}{|c|}{ Rank } & \multirow{2}{*}{ Division } & \multicolumn{3}{|c|}{ Rank } \\
\hline & 2014 & 2015 & 2016 & & 2014 & 2015 & 2016 & & 2014 & 2015 & 2016 \\
\hline 05 & 82 & 85 & 72 & 16 & 46 & 56 & 53 & 27 & 38 & 15 & 58 \\
\hline 06 & 87 & 90 & 89 & 17 & 36 & 49 & 34 & 28 & 13 & 14 & 21 \\
\hline 08 & 37 & 30 & 45 & 18 & 51 & 54 & 57 & 29 & 11 & 23 & 32 \\
\hline 09 & 73 & 77 & 75 & 19 & 26 & 48 & 42 & 31 & 28 & 16 & 12 \\
\hline 10 & 69 & 67 & 65 & 20 & 7 & 5 & 4 & 32 & 47 & 40 & 29 \\
\hline 11 & 25 & 1 & 35 & 21 & 55 & 24 & 9 & 33 & 44 & 39 & 61 \\
\hline 12 & 81 & 76 & 78 & 22 & 20 & 10 & 8 & 35 & 60 & 74 & 50 \\
\hline 13 & 27 & 62 & 33 & 24 & 52 & 41 & 17 & 36 & 86 & 84 & 83 \\
\hline 14 & 63 & 71 & 68 & 25 & 2 & 3 & 6 & 38 & 66 & 70 & 64 \\
\hline 15 & 22 & 59 & 31 & 26 & 18 & 19 & 43 & 39 & 79 & 88 & 80 \\
\hline
\end{tabular}

Source: own study

Even though the gross value added increased in the Industry sector over the whole period, the observed improvement in financial performance was not equally distributed across all the divisions. Some of them performed better while others - worse. It follows that apart from economic growth there were also other factors at play.

Performance of companies in the Construction sector was not stable over time. Detailed information for individual divisions is shown in Table 5.

Despite an overall drop in gross value added in this sector, financial performance of companies in Division 41 Construction of buildings continued to systematically improve, unlike in the other two divisions, i.e. Division 42 Works related to construction of civil engineering, and Division 43 Specialised construction activities, especially in 2016. 
Table 5. Ranking of PKD divisions in sector 3: Construction: section F

\begin{tabular}{|c|c|c|c|}
\hline \multirow{2}{*}{ Division } & \multicolumn{3}{|c|}{ Rank } \\
\cline { 2 - 4 } & $\mathbf{2 0 1 4}$ & $\mathbf{2 0 1 5}$ & $\mathbf{2 0 1 6}$ \\
\hline 41 & 8 & 7 & 4 \\
\hline 42 & 3 & 5 & 9 \\
\hline 43 & 2 & 1 & 6 \\
\hline
\end{tabular}

Source: own study

In the Market services sector, an overall growth in gross value added was observed. The ranking of divisions from the viewpoint of their financial performance is presented in Table 6 .

Table 6. Ranking of PKD divisions in sector 4: Market services: sections $G, H, I, J$

\begin{tabular}{|c|c|c|c|c|c|c|c|}
\hline \multirow{2}{*}{ Division } & \multicolumn{4}{|c|}{ Rank } & \multirow{2}{*}{ Division } & \multicolumn{3}{|c|}{ Rank } \\
\cline { 2 - 3 } & $\mathbf{2 0 1 4}$ & $\mathbf{2 0 1 5}$ & $\mathbf{2 0 1 6}$ & & $\mathbf{2 0 1 4}$ & $\mathbf{2 0 1 5}$ & $\mathbf{2 0 1 6}$ \\
\hline 45 & 46 & 45 & 48 & 55 & 34 & 37 & 36 \\
\hline 46 & 30 & 28 & 33 & 56 & 23 & 25 & 20 \\
\hline 47 & 40 & 39 & 38 & 58 & 24 & 31 & 17 \\
\hline 49 & 14 & 12 & 15 & 59 & 6 & 26 & 11 \\
\hline 50 & 2 & 29 & 35 & 60 & 19 & 32 & 44 \\
\hline 51 & 41 & 1 & 42 & 61 & 9 & 5 & 13 \\
\hline 52 & 16 & 10 & 27 & 62 & 4 & 3 & 7 \\
\hline 53 & 21 & 47 & 43 & 63 & 8 & 22 & 18 \\
\hline
\end{tabular}

Source: own study

In sector 4 Market services, there were companies from Division 62 Computer programming, consultancy and related activities which outperformed their peers. However, the situation worsened in the last year of study. Improvement in position in terms of financial performance in 2016 was observed for companies in Division 58 Publishing activities. The highest decreases throughout the analysed period, on the other hand, were seen in Divisions 50 Water transport and 60 Public and licence programmes broadcasting. A significant reduction in the occupied position also applied to Division 53 Postal and courier activities. However, in the last year of analysis there was a reversal of the unfavourable trend in that Division. Dynamic changes in ranks were observed for Division 51 Air transport, which might have resulted from the small size of the sample.

The ranking of PKD divisions in the next sector, Financial services, is shown in Table 7.

According to the data presented in Table 7, the best financial performance can be seen in Division 65 Insurance, reinsurance and pension funding, except compulsory social security. Over time, however, the position of that division deteriorated, 
despite general growth in the gross value added in the entire sector. In contrast to that, companies in Division 68 Real estate activities reported improved financial performance. Negative changes in positions, especially in 2015 , can be seen in Division 66 Activities auxiliary to financial services and insurance activities and pension funding, and Division 64 Financial service activities, except insurance and pension funding; the condition of companies in the latter division was visibly the worst, as it held the last position each year.

Table 7. Ranking of PKD divisions in sector 5: Financial services: sections K, L

\begin{tabular}{|c|c|c|c|}
\hline \multirow{2}{*}{ Division } & \multicolumn{3}{|c|}{ Rank } \\
\cline { 2 - 4 } & $\mathbf{2 0 1 4}$ & $\mathbf{2 0 1 5}$ & $\mathbf{2 0 1 6}$ \\
\hline 64 & 10 & 12 & 11 \\
\hline 65 & 2 & 1 & 4 \\
\hline 66 & 3 & 8 & 6 \\
\hline 68 & 9 & 7 & 5 \\
\hline
\end{tabular}

Source: own study

Companies from individual divisions of sector 6 Other services are shown in Table 8 providing their positions in the sector's ranking.

Table 8. Ranking of PKD divisions in sector 6: Other services: sections M, N, O, P, Q, R, S

\begin{tabular}{|c|c|c|c|c|c|c|c|}
\hline \multirow{2}{*}{ Division } & \multicolumn{9}{|c|}{ Rank } & \multirow{2}{*}{ Division } & \multicolumn{3}{|c|}{ Rank } \\
\cline { 2 - 3 } & $\mathbf{2 0 1 4}$ & $\mathbf{2 0 1 5}$ & $\mathbf{2 0 1 6}$ & & $\mathbf{2 0 1 4}$ & $\mathbf{2 0 1 5}$ & $\mathbf{2 0 1 6}$ \\
\hline 69 & 6 & 4 & 2 & 82 & 11 & 5 & 7 \\
\hline 70 & 31 & 23 & 26 & 84 & 39 & 13 & 3 \\
\hline 71 & 40 & 33 & 43 & 85 & 49 & 54 & 47 \\
\hline 72 & 46 & 27 & 55 & 87 & 50 & 41 & 24 \\
\hline 73 & 29 & 32 & 36 & 88 & 22 & 44 & 20 \\
\hline 74 & 30 & 38 & 17 & 90 & 68 & 63 & 69 \\
\hline 75 & 18 & 15 & 9 & 91 & 64 & 60 & 67 \\
\hline 77 & 21 & 8 & 25 & 92 & 61 & 66 & 65 \\
\hline 78 & 37 & 28 & 51 & 93 & 53 & 45 & 42 \\
\hline 79 & 34 & 35 & 52 & 94 & 59 & 57 & 62 \\
\hline 80 & 58 & 48 & 56 & 96 & 1 & 10 & 16 \\
\hline 81 & 14 & 12 & 19 & & & & \\
\hline
\end{tabular}

The best financial performance in the entire analysis period was recorded by companies from Division 69 Legal, accounting, bookkeeping and auditing activities; tax consultancy. The most dynamic improvement in position, and hence financial performance, can be seen for divisions: 84 Public administration and defence; compulsory social security and 87 Residential care activities, and 74 Other 
professional, scientific and technical activities, particularly in 2016. On the other hand, the divisions where financial performance deteriorated include: 79 Tour operator, middlemen, agents and other reservation service and related activities, and 96 Other personal service activities. Firms providing services such as washing and (dry-)cleaning of textile and fur products; hairdressing and other beauty treatment; funeral and related activities; physical well-being activities and other personal service activities not elsewhere classified, which were the leader of the 2014 ranking, two years later, in 2016, were ranked $16^{\text {th }}$.

\section{Conclusions}

The theoretical and empirical analyses have led to the following conclusions:

1. Financial performance of companies and PKD divisions, reflecting, on the one hand, their ex-post efficiency and, on the other hand, their future growth opportunities, should become the subject of multidirectional causal analyses of various scopes.

2. The multi-criterial approach to evaluation of financial performance used so far provides partial and scattered information thus preventing the generation of a more holistic picture. For this reason, synthetic measures are sought to enable a more generalised evaluation of performance.

3. A dynamic approach to the taxonomic measure of development allows for comparisons over time, i.e. it reveals a tendency, which offers a greater cognitive value than an evaluation of a single period.

4. Employment of a synthetic measure of financial performance enables ranking the entities under study, i.e. evaluating them in space by indicating their position and distance to the leader, and is always a strong stimulus for improving efficiency of operations.

5. The study indicates that in certain macroeconomic conditions the financial performance of individual sectors and divisions within them can vary. It follows that other determinants of performance remain significant, including those within the management's control.

6. The ranking presented in this paper is an important source of information for policy makers who create a framework for business operations as well as for the senior management and other stakeholders who make decisions leading to the achievement of their individual goals. 


\section{References}

Batóg J. (2003), Klasyfikacja obiektów w przypadku agregacji danych, "Metody Ilościowe w Ekonomii. Uniwersytet Szczeciński, Zeszyty Naukowe”, no. 365, „Prace Katedry Ekonometrii i Statystyki", no. 14, pp. 35-44.

Directive 2014/95/EU of the European Parliament and of the Council of 22 October 2014, OJoEU L330/1 of 15 November 2014.

Dudycz T., Skoczylas W. (2016), Wskaźniki finansowe wedlug działów (sektorów) za rok 2014, "Rachunkowość", no. 3, pp. 70-96.

Dudycz T., Skoczylas W. (2017), Wskaźniki finansowe przedsiębiorstw wedtug działów (sektorów) za 2015 rok, "Rachunkowość", no. 4, pp. 74-100.

Dudycz T., Skoczylas W. (2018), Wskaźniki sektorowe za rok 2016, "Rachunkowość", no. 4, pp. 62-68.

Gabrusewicz W. (2014), Analiza finansowa przedsiębiorstwa. Teoria i zastosowanie, Polskie Wydawnictwo Ekonomiczne, Warszawa.

Gatnar E., Walesiak M. (eds.) (2004), Metody statystycznej analizy wielowymiarowej w badaniach marketingowych, Wydawnictwo Akademii Ekonomicznej we Wrocławiu, Wrocław.

Hadasik D. (1998), Upadłość przedsiębiorstw w Polsce i metody jej prognozowania, Wydawnictwo Akademii Ekonomicznej w Poznaniu, Poznań.

Hamrol M., Czajka B., Piechocki M. (2004), Upadtość przedsiębiorstwa-model analizy dyskryminacyjnej, "Przegląd Organizacji", no. 6, pp. 35-39.

Hellwig Z. (1968), Zastosowanie metody taksonomicznej do typologicznego podziału krajów ze względu na poziom rozwoju oraz zasoby i strukture wykwalifikowanych kadr, "Przegląd Statystyczny", no. 4, pp. 307-327.

Hołda A. (2001), Wykorzystanie analizy dyskryminacyjnej w predykcji bankructwa - doświadczenia światowe, "Zeszyty Teoretyczne Rachunkowości”, no. 5(61), pp. 59-69.

Hwang C.-L., Yoon K. (1981), Multiple Attribute Decision Making. Methods and Applications. A State-of-the-Art Survey, Springer-Verlag, Berlin-Heidelberg-New York.

Kukuła K. (2000), Metoda unitaryzacji zerowanej, Wydawnictwo Naukowe PWN, Warszawa.

Mączyńska E., Zawadzki M. (2006), Dyskryminacyjne modele predykcji upadłości przedsiębiorstw, "Ekonomista", no. 2, pp. 205-235.

Młodak A. (2006), Analiza taksonomiczna w statystyce regionalnej, Difin, Warszawa.

Nowak E. (1990), Metody taksonomiczne w klasyfikacji obiektów społeczno-gospodarczych, Państwowe Wydawnictwo Ekonomiczne, Warszawa.

Nowak E. (2017), Analiza sprawozdań finansowych, Polskie Wydawnictwo Ekonomiczne, Warszawa.

Pietrzykowski R., Kobus P. (2006), Zastosowanie modyfikacji metody $k$-średnich w analizie portfelowej, “Zeszyty Naukowe SGGW - Ekonomika i Organizacja Gospodarki Żywnościowej”, no. 60 , pp. 301-307.

Siemińska E. (2002), Metody pomiaru i oceny kondycji finansowej przedsiębiorstwa, Uniwersytet Mikołaja Kopernika w Toruniu, Torun.

Sierpińska M., Jachna T. (2004), Ocena przedsiębiorstwa według standardów światowych, Wydawnictwo Naukowe PWN, Warszawa.

Siudek T. (2006), Badanie regionalnego zróżnicowania sytuacji ekonomiczno-finansowej banków spótdzielczych w Polsce z wykorzystaniem metod taksonomicznych, "Zeszyty Naukowe SGGW - Ekonomika i Organizacja Gospodarki Żywnościowej”, no. 58, pp. 41-53.

Skoczylas W., Batóg B. (2017), Wykorzystanie taksonomicznego miernika rozwoju w ocenie sytuacji finansowej przedsiębiorstwa. Dylematy zarzadzania kosztami i dokonaniami, "Prace Naukowe Uniwersytetu Ekonomicznego we Wrocławiu", no. 472, pp. 387-397.

Skoczylas W., Batóg B., Sobieraj M. (2017), Ranking sytuacji finansowej dziatów i sekcji działalności gospodarczej w Polsce w 2015 roku, "Rachunkowość", no. 7, pp. 77-85.

Statistics Poland (a), http://stat.gov.pl/Klasyfikacje/doc/pkd_07/pkd_07.htm [accessed: 25.04.2018]. 
Statistics Poland (b), http://stat.gov.pl/wskazniki-makroekonomiczne/ [accessed: 23.05.2018].

Stawicki J., Sojak S. (2001), Wykorzystanie metod taksonomicznych do oceny kondycji ekonomicznej przedsiębiorstw, "Zeszyty Teoretyczne Rachunkowości”, no. 3, pp. 56-67.

Accounting Act of 29 September 1994, Journal of Laws 2018, item 650. [Ustawa z dnia 29 września 1994 r. o rachunkowości - Dz.U. z 2018 r., poz. 650.]

Waśniewski T., Skoczylas W. (2004), Teoria i praktyka analizy finansowej w przedsiębiorstwie, Fundacja Rozwoju Rachunkowości w Polsce, Warszawa.

Witkowska A., Witkowski M. (2014), Klasyfikacja pozycyjna banków spółdzielczych wedtug ich kondycji finansowej w ujęciu dynamicznym, "Prace Naukowe Uniwersytetu Ekonomicznego we Wrocławiu", no. 328, "Taksonomia 23", pp. 126-134.

Zielińska-Chmielewska A., Strózik T. (2015), Ocena klasyfikacji pozycyjnej przedsiębiorstw przetwórstwa mięsnego wedtug stanu ich kondycji finansowej w ujęciu dynamicznym, "Prace Naukowe Uniwersytetu Ekonomicznego we Wrocławiu", no. 402, "Polityka ekonomiczna", pp. 397-408.

\section{Podejście dynamiczne w porównawczej ocenie sytuacji finansowej sekcji i sektorów polskiej gospodarki}

Streszczenie: Sytuacją finansową przedsiębiorstw oraz ich grup stale są zainteresowani wszyscy interesariusze. Podstawowe wskaźniki, które są brane pod uwagę przy ocenie sytuacji finansowej, to rentowność, płynność finansowa, niezależność finansowa i ryzyko. Analiza każdego ze nich z osobna nie zawsze daje jednoznaczne wyniki. W takim przypadku pomocne są metody syntetyczne. Do takich metod należy rangowanie z wykorzystaniem taksonomicznej miary rozwoju. Celem artykułu jest przedstawienie możliwości wykorzystania dynamicznej wersji taksonomicznej miary rozwoju w porównawczej, kompleksowej ocenie sytuacji finansowej działów oraz ocena występujących na przestrzeni trzech lat zmian w tym zakresie. Dane wykorzystane do opracowania rankingu działów pochodzą ze wskaźników sektorowych Komisji Analizy Finansowej Rady Naukowej Stowarzyszenia Księgowych w Polsce, przygotowywanych we współpracy z InfoCredit oraz z Głównego Urzędu Statystycznego.

Słowa kluczowe: sytuacja finansowa, taksonomiczna miara rozwoju

JEL: M21, M40, C38

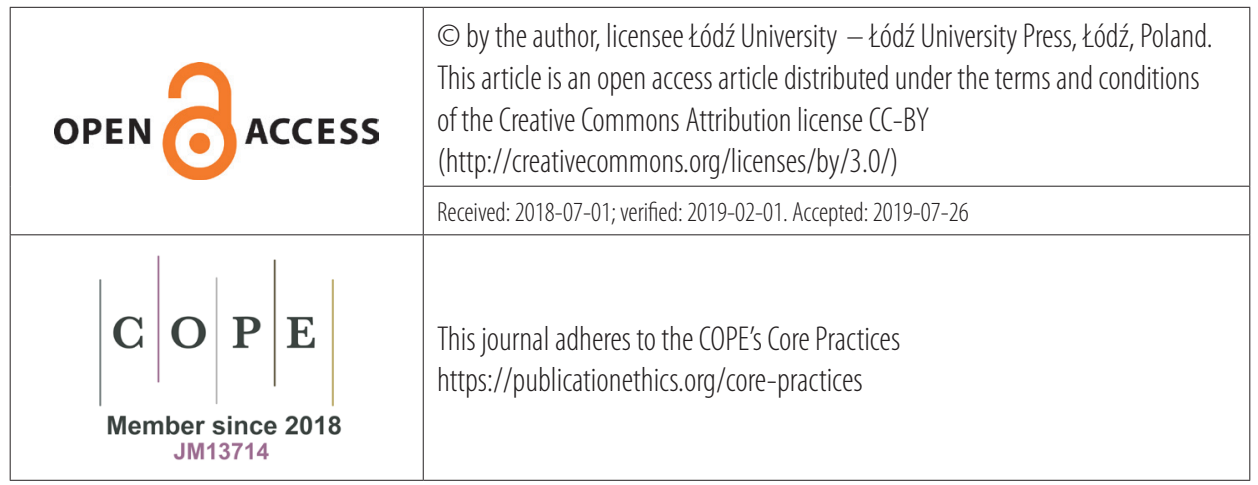

